\title{
In vitro embryo production in small ruminants
}

\section{Vicente José de Figueirêdo Freitas ${ }^{1}$, Luciana Magalhães Melo ${ }^{1}$}

\footnotetext{
${ }^{1}$ Laboratório de Fisiologia e Controle da Reprodução - Faculdade de Veterinária - Universidade Estadual do Ceará.
}

ABSTRACT - This paper reviews the technical bases of in vitro embryo production in small ruminants with special attention to the results obtained by our group in Northeastern Brazil. The laparoscopic oocyte recovery in hormonally treated live animals indicates a promising future for the application of this technique to genetic improvement program. New molecular biology tools should provide information to improve the efficiency of in vitro maturation. Furthers efforts have to be made to improve the oocyte maturation and to standardize the semen-capacitating process.

Key Words: embryo, goat, in vitro production, sheep

\section{Produção in vitro de embriões em pequenos ruminantes}

\begin{abstract}
RESUMO - Este artigo revisa as bases técnicas da produção in vitro de embriões em pequenos ruminantes com especial atenção aos resultados obtidos por nosso grupo no Nordeste do Brasil. A colheita dos oócitos por laparoscopia em animais vivos e hormonalmente tratados aponta para um futuro promissor da aplicação dessa técnica em programas de melhoramento genético. Novas ferramentas de biologia molecular devem fornecer informações para melhorar a eficiência da maturação in vitro. Esforços posteriores devem ser realizados para melhorar os índices de maturação oocitária e para padronizar o processo de capacitação espermática.
\end{abstract}

Palavras-chave: caprino, embriã, ovinoo, produção in vitro

\section{Introduction}

Several achievements have been made in recent years in reproductive biotechnologies in domestic animals. Small ruminants offer a good model for the development of these technologies as, for example, transgenesis and cloning (Freitas, 2003; Freitas et al., 2007).

In the cattle-breeding industry, the overall production of embryos using the recovery of oocytes by ovum pick-up and in vitro production could be estimate as threefold more efficient than superovulation in terms of the production of freezable embryos per cow per year (Merton et al., 2003). Thus, since the birth of lams and kids 23 years ago (Crozet et al., 1987), recent advances in knowledge of oocyte maturation and research on different culture conditions have led to substantial progress in in vitro embryo production (IVEP) systems (Thompson, 2000; Cognié et al., 2004) for small ruminants. Additionally, an efficient system of IVEP can accelerate the results in a genetic improvement program in both sheep and goats herds (Figure 1).

The IVEP system involve four steps: (a) the recovery of primary oocytes from antral follicles; (b) the in vitro maturation (IVM) of these oocytes; (c) the in vitro fertilization (IVF) of the matured oocytes and (d) the in vitro culture (IVC) of the resulting embryos.

This review aims to provide an overview of the stateof-art of the IVEP of small ruminants, with an emphasis on the results obtained by our group working with animals and conditions found in Northeastern Brazil.

Oocyte recovery

Recovery of good-quality oocytes is the first step for IVEP procedure. In small ruminants the methods utilized are: (a) postmortem slicing of the ovaries or aspiration of ovarian follicles (Samake et al., 2000), (b) transvaginal ultrasoundguided ovum pick-up (Graff et al., 1999) and (c) laparoscopic oocyte recovery (LOR) (Baldassarre et al., 1996). The first method is useful for research purposes, but cannot be acceptable for commercial use while the transvaginal ultrasonographic approach presents a very low oocyte recovery rate (approximately 30\%). Oocyte recovery from live animals accomplished by LOR has been developed in sheep and goats with an oocyte recovery rate close to $80 \%$ (Baldassarre et al., 2002).

In our laboratory, the great difficulty has been the low quality of the ovaries collected in slaughter. The majority 


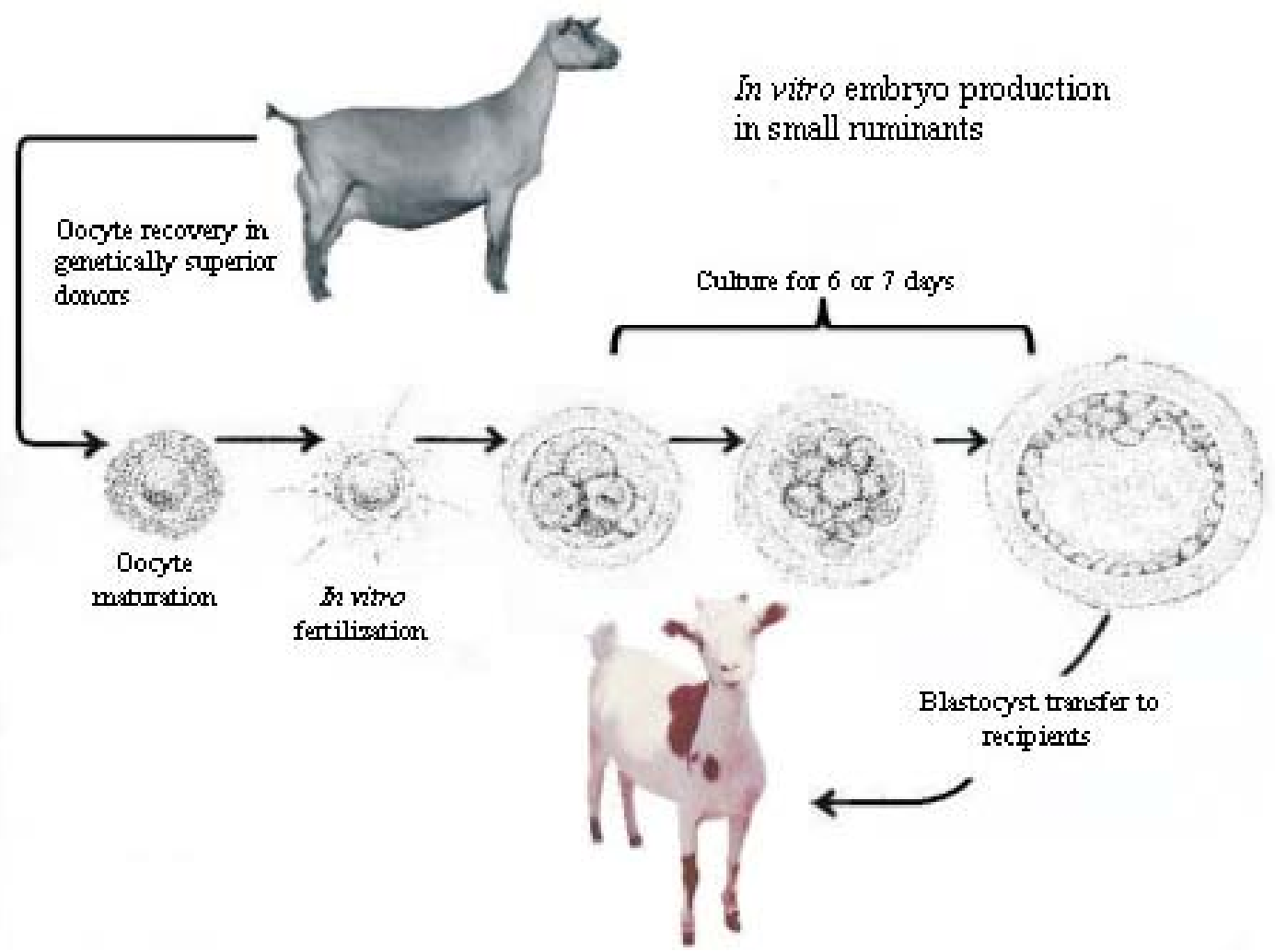

Figure 1 - Schematic figure of a genetic improvement program based on in vitro embryo production (IVEP) system in small ruminants.

of these ovaries is small and deriving from animals in poor sanitary and nutritional conditions.

The LOR method, in hormonally treated females, provides a good oocyte number per donor per session. In order to obtain good-quality oocytes to an IVEP program, our group treated Canindé goats with a progestagen priming for 11 days associated to a one-shot injection of FSH-eCG or to five injections of FSH in decreasing doses. No significant differences were recorded between the hormonal treatments tested, regarding the mean number of follicles visualized and aspirated. The mean number of cumulus-oocyte complexes (COC's) recovered per donor did not statistically differ between treatments and was $12.4 \pm 1.0$ and $10.8 \pm 1.0$ for the five injections and one-shot treatments, respectively (Avelar, 2009).

Apart from the gonadotrophin treatment, the interval between stimulation and aspiration is important and seems optimal when follicles are aspirated between 36 to $48 \mathrm{~h}$ after the gonadotrophin injection. Finally, to maintain adhesion of cumulus cells to sheep and goat oocytes, we routinely use $22 \mathrm{G}$ needles adapted to silicon tubing under $30 \mathrm{mmHg}$ aspiration vacuum. In addition, our experience with the morphology of COC's recovered from local goats led us to propose new criteria for assessing the quality of these COC's (Table 1).

IVM of primary oocytes

Acquisition of oocyte developmental competence occurs continuously throughout folliculogenesis and the influence of follicular size and follicular atresia was reviewed by Mermillod et al. (1999).

Embryo development is influenced by events occurring during oocyte maturation. For successful IVM, oocytes must undergo synchronically nuclear and cytoplasmic

Table 1 - Criteria for grading cumulus-oocyte complexes (COC’s) recovered from goats raised in Northeastern Brazil

\begin{tabular}{ll}
\hline Characteristic & Grade \\
\hline Multilayered compact cumulus and finely granulated oocyte cytoplasm & 1 \\
One to three layers of cumulus cells and finely granulated oocyte cytoplasm & 2 \\
Incomplete or no cellular investment or heterogeneous oocyte cytoplasm & 3 \\
Oocyte with abnormal shape and heterogeneous oocyte cytoplasm or apoptotic & 4 \\
oocytes in jelly-like cumulus-corona cells investment &
\end{tabular}


maturation. Immature oocytes are conventionally matured in buffered TCM-199 supplemented with L-glutamine, pyruvate, hormones (FSH, LH and 17b-estradiol) plus serum.

In our laboratory, the maturation medium is composed by TCM-199 supplemented with cysteamine, epidermal growth factor and gentamicin. Oocytes are matured by incubation in this medium at $38.5^{\circ} \mathrm{C}$ in humidified atmosphere of $5 \% \mathrm{CO}_{2}$ in air.

Follicular fluid from non-atretic and large follicles has been used as a compound of IVM medium (Cognié et al., 2003). However, estrus goat serum and follicular fluid need to be tested before being used in a protocol of IVEP because both compounds present high chemical variations between samples. Rodriguez-Dorta et al. (2007) in adult goat oocytes used a maturation medium with defined compounds. The IVM medium used, similar to our laboratory, is TCM-199 supplemented with $10 \mathrm{mg} / \mathrm{ml}$ EGF and $100 \mathrm{mM}$ cysteamine, with good results in embryo development. The addition of different thiol compounds (cysteamine for example) to the IVM medium improves embryo development, increases intra-cytoplasmic glutathione concentration (GSH) and protects cells from culture oxidative stress (Cognié et al., 2003).

Since the oocyte developmental competence has been associated with in vivo transcript accumulation, which is important for embryo development up to the genome activation (Dieleman et al., 2002), it is not surprising that the competence of in vitro matured oocytes is determined by factors such as hormonal stimulation and the origin of the oocyte (Webb et al., 2007). In this light, our group tried to determine the effect of two FSH protocols for ovarian stimulation (5 vs 3 injections) in goats on the expression pattern of Epidermal Growth Factor Receptor (EGFR) in COC's. After real-time qRT-PCR analysis, expression profiles of morphologically graded COCs' were compared prior to and after IVM. The use of a protocol with higher number of FSH injections resulted in G1/G2 COC's with a higher level of EGFR expression in cumulus cells, but not in the oocyte, which was correlated with an elevated meiotic competence following IVM(Almeida et al., 2009). In summary, differential EGFR expression in goat cumulus cells was associated with the in vivo prematuration process, and in turn, the up regulation in the entire COC's was associated with IVM. Cause-and-effect relationships between such increased expression levels, particularly in the oocyte, and oocyte competence itself still need to be further investigated.

\section{IVF of matured oocytes}

Most IVF studies use freshly ejaculated spermatozoa and a few IVF trials have been carried out with frozen- thawed spermatozoa. In our laboratory, following a maturation period, the cumulus cells are removed by gentle pipeting and oocytes are washed in IVF medium. Oocytes are placed in four-well dishes containing Synthetic Oviduct Fluid (SOF) medium and heat-treated estrus goat serum. Motile spermatozoa are obtained by centrifugation of semen on a Percoll gradient (45\%/90\%) for 10 minutes at $900 \mathrm{~g}$. Viable spermatozoa are incubated for 30 minutes in medium supplemented with heat-inactivated estrus goat serum for their capacitation. This phenomenon leads to "acrosome reaction" causing the release of proteolytic enzymes that may assist sperm penetration into the oocyte. Any agent that causes $\mathrm{Ca}++$ entry into the sperm acrosome and an increase of $\mathrm{pH}$ within the sperm enables capacitation to be accomplished. Capacitation-stimulating heparin may be added to the medium. Oocytes and capacitate spermatozoa are placed at $38.5^{\circ} \mathrm{C}$ in humidified atmosphere of $5 \% \mathrm{CO}_{2}$ in air for $18 \mathrm{~h}$.

Intra-Cytoplasmic Sperm Injection (ICSI) has been introduced as an alternative to assisted reproduction technology, especially in humans. The Spanish group led by Dr. Paramio is one of the foremost experts in this technique applied in goats. A major application of this technique for animal production includes use of genetically important male gametes for procreating wild and domestic animals. Moreover, this technique can be used to extend the sperm vector for transgenic animal production and to use freezedried sperm for which spermatozoa motility is not required. The first live kids have been obtained by Wang et al. (2003).

\section{IVC of resulting embryos}

After $24 \mathrm{~h}$ post-insemination, presumptive zygotes are removed from the fertilization medium and placed in an embryo culture medium. Early small ruminant embryos cultured in vitro fail to develop past the 8- to 16-cell stages in traditional culture medium. This block occurred around the time of activation of the embryonic genome (Pviko et al., 1995). This block occurred around time of activation of the embryonic genome. Serum and cells are added to the culture to avoid this block.

Three culture systems are routinely used for IVEP in small ruminants: (a) coculture with somatic cell support; (b) semidefined conditions in medium designed to suit embryo requirements; or (c) in vivo development in oviducts. The comparison between coculture vs semi-defined medium demonstrate that the culture treatment does not influence the rate of developmental of IVC in both sheep (Holm et al., 1994) and goat (Izquierdo et al., 2002) oocytes. However, if culture systems do not significantly affect blastocyst yields in small ruminants, the oviduct environment clearly 
improves the overall quality of blastocysts (Tervit et al., 1994).

In our laboratory, we routinely use a semidefined system for the culture of embryos with SOF medium supplemented with bovine serum albumin (BSA) at $38.5^{\circ} \mathrm{C}$ in $5 \% \mathrm{O}_{2}, 5 \% \mathrm{CO}_{2}$ and $90 \% \mathrm{~N}_{2}$ humidified atmosphere for five or six days.

Recent progress in the understanding of the requirements of the developing embryo resulted in development of medias where components change according to the needs of the embryo. However, the differences between in vitro- and in vivo-derived embryos show that in vitro procedures need to be improved (Table 2).

\section{Embryo cryopreservation}

Advancements and factors affecting the efficiency of cryopreservation of domestic animal embryos have been recently reported. Sheep and goat embryos are able to survive vitrification procedures, and this method may provide an economical alternative to the current freezing methods that require gradual dehydration of embryonic cells (Baril et al., 2001). Vitrification does not require any special equipment and, therefore, may be very well adapted to routine field use. Furthermore, this ultra rapid technique may be more adapted to embryos with a higher cryosensitivity, such as in vitro-produced, biopsied, or cloned embryos (Vajta, 2000).

There are fundamental differences in the cellular structure and biochemistry between in vivo- and in vitroderived embryos that significantly affect their sensitivity to freezing (Massip, 2001). In addition, Leoni et al. (2009) compared the developmental capacity and cryotolerance to vitrification of embryos produced from oocytes of stimulated prepubertal and adult Sarda goats. Compared with the adult, prepubertal vitrified/warmed blastocysts showed significantly lower in vitro viability, as determined by the re-expansion rate (62.5 and 40.3\%). These results showed that in vitro-produced embryos produced from prepubertal goat oocytes have a lower developmental rate and cryotolerance compared with their adult counterparts.

Table 2 - Kidding and embryo survival rate after transfer of fresh embryos in vivo- or in vitro- produced in goats

\begin{tabular}{|c|c|c|c|c|c|c|}
\hline \multirow[t]{2}{*}{ Method } & \multirow{2}{*}{$\begin{array}{c}\text { Recipients } \\
n\end{array}$} & \multirow{2}{*}{$\begin{array}{c}\text { Embryos } \\
n\end{array}$} & \multicolumn{2}{|c|}{ Kidding } & \multicolumn{2}{|c|}{ Kids borns/transferred embryos } \\
\hline & & & $\%$ & $n$ & $\%$ & $n$ \\
\hline In vivo & 19 & 38 & $89^{a}$ & 17 & $71^{\mathrm{a}}$ & 27 \\
\hline In vitro & 18 & 36 & $61^{\mathrm{b}}$ & 11 & $47^{b}$ & 17 \\
\hline
\end{tabular}

Within columns, values with different superscripts are significantly different $(\mathrm{P}<0.05)$ (Cognié et al., 2003).

\section{Conclusions}

Gazing into a crystal ball and predicting future developments in IVP in small ruminants and its commercial applications is not a very easy occupation. However, one can perhaps safely predict that procedures for oocyte recovery in live animals and for improve the oocyte maturation and the semen-capacitating process will continue to be developed and will have a major impact for the next years.

\section{Acknowledgments}

We thank the Conselho Nacional de Desenvolvimento Científico e Tecnológico (CNPq) and Fundação Cearense de Apoio ao Desenvolvimento Científico e Tecnológico (FUNCAP) for financial support. V.J.F. Freitas is senior investigator of CNPq and L.M. Melo is a recipient of the Programa Nacional de Pós-Doutorado-Coordenação de Aperfeiçoamento de Pessoal de Nível Superior (PNPDCAPES) research scholarship.

\section{References}

ALMEIDA, K.C. RT-PCR quantitativo em tempo real para análise do receptor de EGF em complexos cumulus-oócito colhidos por laparoscopia em cabras Canindé submetidas à estimulação ovariana. 2009. 88f. Dissertação (Programa de Pós-Graduação em Ciências Veterinárias) - Universidade Estadual do Ceará, Fortaleza.

AVELAR, S.R.G. Diferentes protocolos de estimulação ovariana para produção de oócitos em cabras da raça Canindé. 2009. 66f. Dissertação (Programa de Pós-Graduação em Ciências Veterinárias) - Universidade Estadual do Ceará, Fortaleza.

BALDASSARRE, H.; FURNUS, C.C.; DE MATOS, D.G. et al. In vitro production of sheep embryos using laparoscopic folliculocentesis alternative gonadotrophin treatments for stimulation of oocyte donors. Theriogenology, v.45, p.707717, 1996.

BALDASSARRE, H.; WANG, B.; KAFIDI, N. et al. Advances in the production and propagation of transgenic goats using laparoscopic ovum pick-up and in vitro embryo production technologies. Theriogenology, v.57, p.275-284, 2002.

BARIL, G.; TRALDI, A.L.; COGNIÉ, Y. et al. Successful direct transfer of vitrified sheep embryos. Theriogenology, v.56, p.299-305, 2001.

COGNIÉ, Y.; BARIL, G.; POULIN, N. et al. Current status of embryo technologies in sheep and goat. Theriogenology, v.59, p.171188, 2003. 
COGNIÉ, Y.; POULIN, N.; LOCATELLI, Y. et al. State-of-theart production, conservation and transfer of in-vitroproduced embryos in small ruminants. Reproduction, Fertility and Development, v.16, p.437-445, 2004.

CROZET, N.; HUNEAU, D.; DESMEDT, V. et al. In vitro fertilization with normal development in the sheep. Gamete Research, v.16, p.159-170, 1987.

DIELEMAN, S.J.; HENDRIKSEN, P.J.M.; VIUFF, D. et al. Effects of in vivo prematuration and in vivo final maturation on developmental capacity and quality of pre-implantation embryos. Theriogenology, v.57, p.5-20, 2002.

GRAFF, K.J.; MEINTJES, M.; DYER, V.W. et al. Transvaginal ultrasound-guided oocyte retrieval following FSH stimulation of domestic goats. Theriogenology, v.51, p.1099-1119, 1999.

FREITAS, V.J.F. Transgênese na espécie caprina. Revista Brasileira de Reprodução Animal, v.27, p.109-115, 2003.

FREITAS, V.J.F.; SEROVA, I.A.; ANDREEVA, L.E. et al. Production of transgenic goat (Capra hircus) with human Granulocyte Colony Stimulating Factor (hG-CSF) gene in Brazil. Anais da Academia Brasileira de Ciências, v.79, p.585-592, 2007.

HOLM, P.; WALKER, S.K.; PETERSEN, B.A. et al. In vitro vs in vivo culture of ovine IVM/IVF ova: effect on lambing. Theriogenology, v.41, p.217, 1994.

IZQUIERDO, D.; VILLAMEDIANA, P.; LOPEZ-BEJAR, M. et al. Effect of in vitro and in vivo culture on embryo development from prepubertal goat IVM/IVP oocytes. Theriogenology, v.57, p.1431-1441, 2002.

LEONI, G.G.; SUCCU, S.; SATTA, V. et al. In vitro production and cryotolerance of prepubertal and adult goat blastocysts obtained from oocytes collected by laparoscopic oocytepick-up (LOPU) after FSH treatment. Reproduction Fertility and Development, v.21, p.901-908, 2009.

MASSIP, A. Cryopreservation of embryos of farm animals. Reproduction in Domestic Animals, v.36, p.49-55, 2001.
MERMILLOD, P.; OUSSAID, B.; COGNIÉ, Y. Aspects of follicular and oocyte maturation that affect the developmental potential of embryos. Journal of Reproduction and Fertility, v.54, p.449-460, 1999.

MERTON, J.S.; DE ROOS, A.P.; MOLLAART, E. et al. Factors affecting oocyte quality and quantity in commercial application of embryo technologies in the cattle breeding industry. Theriogenology, v.59, p.651-674, 2003.

PIVKO, J.; GRAFENAU, P.; KOPECNY, V. Nuclear fine structure and transcription in early goat embryos. Theriogenology, v.21, p.126-137, 1995.

RODRIGUEZ-DORTA, N.; COGNIÉ, Y.; GONZÁLEZ, F. et al. Effect of coculture with oviduct epithelial cells on viability after transfer of vitrified in vitro produced goat embryos. Theriogenology, v.68, p.908-913, 2007.

SAMAKE, S.; AMOAH, E.A.; MOBINI, S. et al. In vitro fertilization of goat oocytes during the nonbreeding season. Small Ruminant Research, v.35, p.49-54, 2000.

TERVIT, H.R.; PUGH, P.A.; MCGOWAN, L.T. et al. The freezeability of sheep embryos is affected by culture systems and source (in vivo or in vitro derived). Theriogenology, v.41, p.315.

THOMPSON, J.G. In vitro culture and embryo metabolism of cattle and sheep embryos: a decade of achievement. Animal Reproduction Science, v.60-61, p.263-275, 2000.

VAJTA, G. Vitrification of the oocytes and embryos of domestic animals. Animal Reproduction Science, v.60-61, p.357364, 2000.

WEBB, R.; GARNSWORTHY, P.C.; CAMPBELL, B.K. et al. Intra-ovarian regulation of follicular development and oocyte competence in farm animals. Theriogenology, v.68, p.22-29, 2007.

WANG, B.; BALDASSARRE, H.; PIERSON, J. et al. The in vitro and in vivo development of goat embryos produced by intracytoplasmic sperm injection using tail-cut spermatozoa. Zygote, v.11, p.219-227, 2003. 